\title{
Dental Clinic Income Analysis at RSU Rajawali Citra
}

\author{
Shanti Yuniwardani ${ }^{1}$, Iwan Dewanto ${ }^{2}$ \\ * University of Muhammadiyah Yogyakarta, Indonesia \\ ** Universitas Muhammadiyah Yogyakarta, Indonesia \\ DOI: 10.29322/IJSRP.11.11.2021.p11911 \\ http://dx.doi.org/10.29322/IJSRP.11.11.2021.p11911
}

\begin{abstract}
This study aims to analyze the income of the dental clinic at RSU Rajawali Citra Bantul which has never been done before, with the aim of identifying the group of actions and what types of actions that contribute to the most income in the dental poly at RSU Rajawali Citra Bantul. This study uses a quantitative approach with descriptive observational methods equipped with interviews. Data were collected by documenting dental clinic financial statements and NHI claim reports from the hospital insurance division from 2018 to 2020. The results showed that the dental poly income of RSU Rajawali Citra is always positive, the action group for general patients who contributed the largest dental clinic income from from 2018 to 2020 is the dental filling group, while in NHI patients it is the pulp treatment group. In general patients, the type of procedure that contributed the most to the income of the dental clinic in 2018 was heavy scaling, in 2019 it was a very large composite filling, and in 2020 it was replacing the rubber bracket/control bracket, while in NHI patients in 2018 it was root canal preparation + dressing package 3, and from 2019 to 2020 the type of root canal sterilization package 3 was the type of procedure that contributed the most to the income of the dental clinic at RSU Rajawali Citra Bantul.
\end{abstract}

Keyword- Income, dental poly, INA CBGs, NHI

\section{INTRODUCTION}

A ccording to the Regional Oral Health Strategy 2013-2020, dental and oral diseases are the fourth most expensive disease to treat, and often require high out-of-pocket financing. The results of Riskedas 2018 noted that the proportion of dental and oral problems in Indonesia was $57.6 \%$ and those who received services from dental medical personnel were only $10.2 \%$. The National Health Insurance Program (NHI) which was developed by the government as part of the National Social Security System (NSSS), has the aim of protecting the entire population of Indonesia through the insurance system by paying dues or contributions paid by the government, so that basic public health needs can be met [1].

The implementation of NHI in Indonesia is a challenge to be able to make changes to services that are more structured. The service concept of the NHI system divides services into 3 service structures, namely primary, secondary and tertiary services. Rajawali Citra Hospital is a type D hospital that serves dental and oral care at the secondary service level.

Rajawali Citra Hospital is one of the private hospitals in Bantul Regency that has served JKN patients since 2016. Since serving JKN patients, the number of visits to the dental clinic at RSU Rajawali Citra has been dominated by NHI patients. The number of patient visits, both general patients and NHI patients, increased from year to year and began to decline in 2020. So far, income analysis has never been carried out by the management of the dental poly at Rajawali Citra Hoaspital. Revenue analysis is the first step that can be taken to develop a service development strategy. Based on this, the researcher is interested in conducting research to analyze the income of the dental clinic at Rajawali Bantul Hospital.

Revenue is the amount charged to customers for goods and services sold. Revenue can also be defined as a gross increase in capital (usually through the receipt of an asset from a customer) derived from goods and services sold [2]. The income/profit of a company or organization can be divided into 2, namely: (a) Gross income, namely income earned before deducting costs that are the company's burden. (b) Net income, which is income that has been deducted by costs that are the company's expense in a certain period, including taxes [3].

\section{RESEARCH METHOD}

This research was kind of observasional descriptive completed with interview, the methode of this research is quantitative methode. It use total sampling which is all of the population include to be a sample, the sample itself was all of the finance annual report for dental clinic, and Claim of INA-CBGs data at Rajawali Citra from 2018 to 2020. The data taken by documentation of secondary data from Annual report of finance department and claim of INA-CBGs report on 2018 and 2020.

\section{WRITE DOWN YOUR STUDIES AND FINDINGS}

This publication is licensed under Creative Commons Attribution CC BY.

http://dx.doi.org/10.29322/IJSRP.11.11.2021.p11911

wWw.ijsrp.org 
Figure 1. Amount of Patient's Visitation at Dental Clinic of Rajawali Citra Hospital

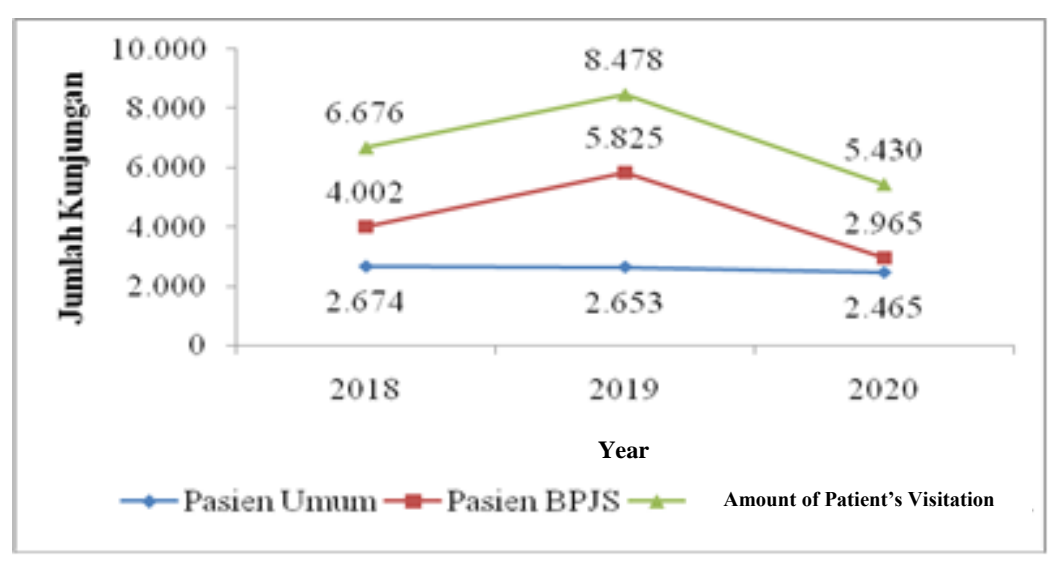

The results showed that the decline in the income of the dental clinic of Rajawali Citra Hospital in 2020 could be due to the decrease in the number of patient visits that year, a drastic decrease occurred in NHI patient visits, while general patients could be considered more stable. This is because in 2020 there was a policy change from NHI, where in dental services at second-level health facilities, one of which is Rajawali Citra Hospital, all NHI patients can only be handled by specialist dentists, in contrast to 2018 and 2019 where NHI patients are still can be handled by general dentists at Rajawali Citra Hospital which has the status of a type D hospital. In addition, the Covid 19 pandemic that hit Indonesia starting in March also indirectly affected the decline in patient visits and income from the dental clinic at Rajawali Citra Hospital.

Table 1. Annual Income of Rajawali Citra Hospital's dental Clinic

\begin{tabular}{|c|c|c|c|}
\hline & 2018 & 2019 & 2020 \\
\hline Total income from general patient & $300.977 .000,00$ & $359.473 .000,00$ & $326.583 .600,00$ \\
\hline Total income from NHI patient & $462.649 .000,00$ & $760.801 .000,00$ & $408.883 .250,00$ \\
\hline Total income $(A)$ & 763.626.000,00 & 1.120.274.000,00 & $735.466 .850,00$ \\
\hline \multicolumn{4}{|l|}{ Expenditure } \\
\hline Clinic's spending & $31.764 .950,00$ & $44.453 .850,00$ & $59.520 .391,50$ \\
\hline Dentist medical service cost & $355.924 .000,00$ & $535.444 .000,00$ & $345.742 .750,00$ \\
\hline Maintenance cost & $686.000,00$ & $1.485 .000,00$ & $1.030 .000,00$ \\
\hline Consumable cost & $139.890 .912,00$ & $206.299 .395,00$ & $165.447 .442,00$ \\
\hline Impression material cost & $23.870 .000,00$ & $28.625 .000,00$ & $10.030 .000,00$ \\
\hline Administration cost & 0,00 & 0,00 & $4.687 .000,00$ \\
\hline Insurence and etc & & $7.705 .350,00$ & $9.408 .500,00$ \\
\hline Total expenditure (B) & $552.135 .862,00$ & 816.307.245,00 & $595.866 .083,50$ \\
\hline Dental clinic profit (A-B) & $211.490 .138,00$ & $303.966 .755,00$ & $139.600 .766,50$ \\
\hline
\end{tabular}

The results of the study show that the income of the dental clinic is positive every year, but there are some expenses that are not recorded in the annual report closing the book of the dental polyclinic, namely the maintenance and administrative costs. This is a weakness in the recapitulation of hospital dental poly income calculations, so that the profits obtained are still not fully net profits, but the profits that have not been deducted are some of the maintenance costs and administrative costs that have not been recorded in the hospital's finance department.

\section{Dental Clinic Income for the treatment group}

The profit of the dental clinic is one of the details of the tariff charged to the patient in each examination which is part of the income for the dental clinic. The profit of clinic and dentist medical services also does not depend on NHI claims obtained by the hospital, but depends on the hospital tariff. This causes the hospital dental clinic to rarely experience losses in handling NHI patients even though the number of NHI patients at RSU Rajawali Citra is fairly large. The following is the flow of claims from NHI patients at RSU Rajawali:

Claim's file flow:

The SEP file from the cashier is sent to the registration unit and then submitted to the insurance unit, the insurance unit will select the file and perform data entry and then make a collective claim recapitulation every month.

Verification process at $\mathrm{NHI}$

Hospital's file accepted by verificator - purification process - proses verification process - realese news Claim filing administration flow 
News file signed by the hospital director- file sent to NHI to get sign from the head of NHI - queue at NHI Finance.

From the cooperation agreement it has been agreed that the money will be received by the hospital from NHI a maximum of 14 days from the time the file is received by NHI and an official report on the completeness of the file is made, after the claim money is received by the hospital then the money is distributed by the finance department to each outpatient and inpatient poly according to the predetermined hospital rates, thats why we can count the profit for each treatment from the NHI patient as well. The rest of the NHI claims are absorbed by the hospital to be distributed to units whose claims are minus. this is referred to as cross-subsidies by the hospital. The analysis of poly profits was carried out with the aim of finding out what types of actions contributed to the largest and smallest income in the dental clinic of Rajawali Bantul hospital. Dental clinic's income for treatment group will describe on this tabel:

Table 3. Profit from the Dental Clinic of RSU Rajawali Bantul Based on Hospital Needs Expenditures for Dental Clinic

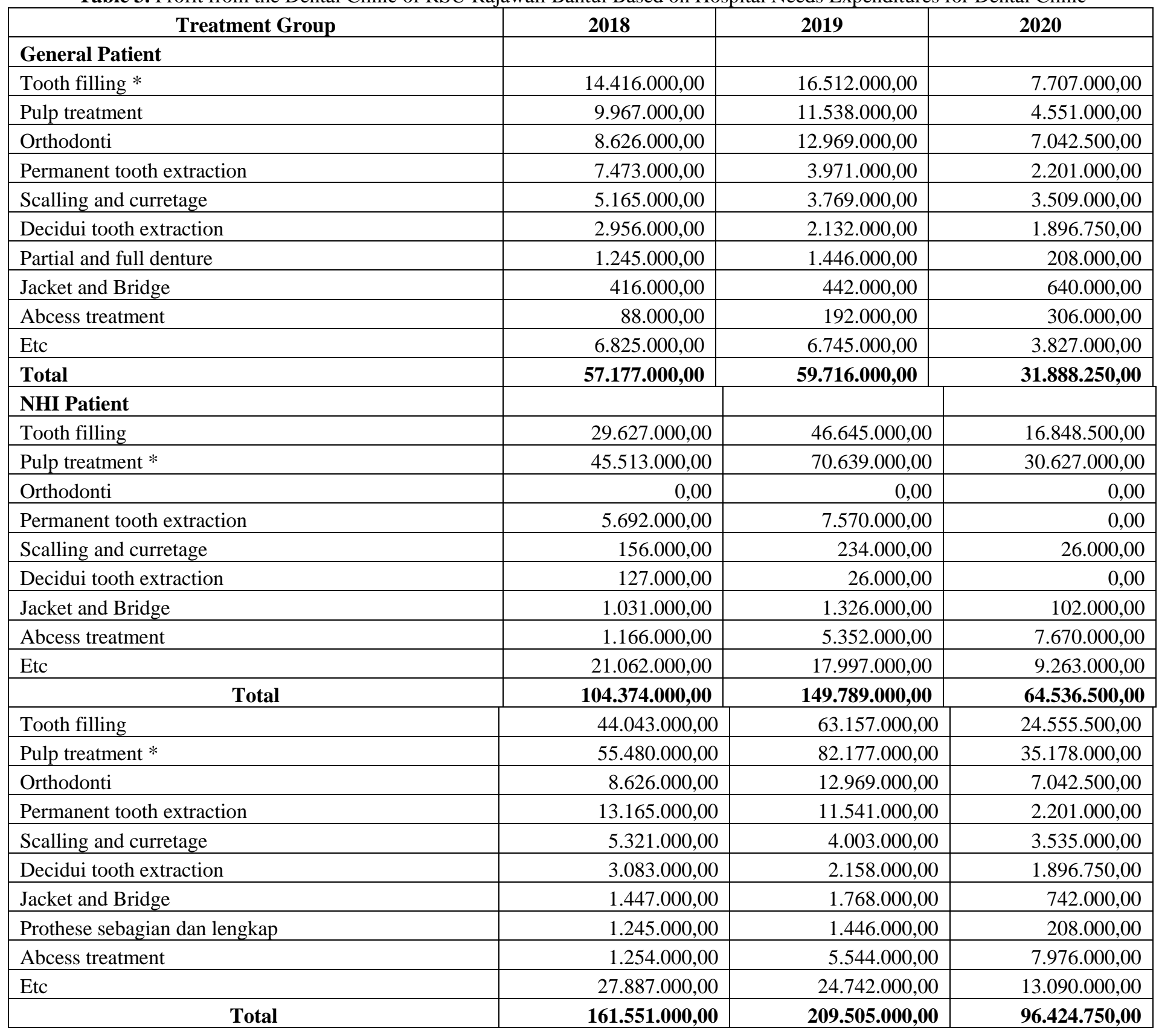

When viewed from the treatment group, in general patients the treatment group that contributed the most income for 2018 to 2020 was dental fillings, while in NHI patients it was the pulp treatment group. These results are due to the fact that the grouping of dental pulp and filling treatments has many types of treatment in it and the number of users of these services is relatively large compared to other services at the dental clinic of Rajawali Citra hospital. The grouping of treatment carried out by the dental clinic at RSU Rajawali Citra is intended to make it easier for nurses and those in charge of the clinic to make monthly report. 


\section{Income of dental clinic for each type of treatment}

When viewed from the type of procedure, the types of procedures that contribute to the largest income in dental clinics from general patients each year are somewhat different, namely heavy scaling in 2018, large composite fillings in 2019 and orthodontic treatment in 2020. This is due to a changing trend from the community around Rajawali Citra Hospital. For NHI patients, the types of procedures that contribute the most income to dental clinics tend to be the same from 2018 to 2020 , namely multiple root canal preparation + dressing package 3 in 2018, and Package 3 root canal sterilization in 2019 and 2020. Types of procedures for patients NHI which contributes the largest income to dental clinics can be identified because in practice, both general patients and NHI patients all rates use rates that have been determined by the hospital along with the details of the tariff per action.

\section{Dental Clinic's income from general dentist and specialized dentist at Rajawali Citra Hospital}

Table 5. Dental Clinic's income from general dentist and specialized dentist at Rajawali Citra Hospital

\begin{tabular}{|c|c|c|c|}
\hline Dentist & 2018 & 2019 & 2020 \\
\hline \multicolumn{4}{|l|}{ General Patient } \\
\hline Specialized Dentist & $3.808 .000,00$ & $2.114 .000,00$ & $3.689 .000,00$ \\
\hline General Dentist & $53.369 .000,00$ & $57.602 .000,00$ & $28.199 .250,00$ \\
\hline Total & $57.177 .000,00$ & $59.716 .000,00$ & $31.888 .250,00$ \\
\hline \multicolumn{4}{|l|}{ NHI Patient } \\
\hline Specialized Dentist & $32.637 .000,00$ & $55.206 .000,00$ & $63.253 .500,00$ \\
\hline General Dentist & $71.737 .000,00$ & $94.583 .000,00$ & $1.283 .000,00$ \\
\hline Total & 104.374.000,00 & 149.789.000,00 & $64.536 .500,00$ \\
\hline \multicolumn{4}{|c|}{ Pasien Umum dan Pasien NHI } \\
\hline Specialized Dentist & $36.445 .000,00$ & $57.320 .000,00$ & $66.942 .500,00$ \\
\hline General Dentist & $125.106 .000,00$ & $152.185 .000,00$ & $29.482 .250,00$ \\
\hline Total & 161.551.000,00 & $209.505 .000,00$ & $96.424 .750,00$ \\
\hline
\end{tabular}

When viewed from the doctor who performs the procedure, in 2018 and 2019, the actions of general dentists provide greater income than the actions provided by specialist dentists. Meanwhile, in 2020, dental specialist procedures will provide greater income than the procedures provided by general dentists. Rajawali Citra hospital just started cooperation with NHI in 2016, at that time RSU Rajawali Citra as a type D hospital did not yet have a specialist dentist, so all cases of NHI patients were still handled by general dentists, Rajawali Citra hospital only had a dentist who specialized in dental conservation in 2018, so that in 2018 and 2019, all dental procedures at RSU Rajawali Citra, both general patients and NHI patients can be carried out by general dentists and specialist dentists, RSU Rajawali Citra has 4 general dentists and 1 specialist dentist conservation of teeth in 2018 and 2019, so that the income from dental polyclinics from patients served by general dentists is greater than that of specialist dentists, in addition to the greater number of medical services received by general dentists compared to specialist dentists, this This of course affects the expenditure of dental poly. The research by [4] shows that hospitals are efficient in responding to the design of health insurance contracts, by adopting cost-effective technology in health services. The high caries rate in Indonesia and the high cost of dental services are one of the factors causing the number of visits by BPJS patients with large cavities or diseased teeth. The problem of dental caries is not only a problem in the area around RSU Rajawali Citra, but occurs in almost all parts of the world. Worldwide, approximately 2.43 billion people (36\% of the population) have dental caries in their permanent teeth. Milk teeth affect about 620 million people or $9 \%$ of the population [5].

In contrast to 2018 and 2019, in 2020 there was a policy change from NHI, where in dental services at the second health facility, all NHI patients can only be handled by specialist dentists because Rajawali Citra hospital already has a dentist who specializes in dental conservation. In addition, Rajawali Citra hospital added 1 more dentist who specializes in dental conservation and added a new room for dentists who specialize in dental conservation. This causes in 2020, the income from the actions performed by specialist dentists on NHI patients to be much greater than that of general dentists, so that in 2020, specialist dentists provide greater income than those provided by general dentist.

\section{CONCLUSION}

The income of the dental clinic as a whole tends to be positive, even though there is a decrease in the number of patients which affects the decline in income in 2020. There are some expenses that are not recorded properly, so it is possible that the income reported by the finance department is not fully net income from the dental clinic of Rajawali Citra Hospital. In general patients, the treatment groups that contributed the most income for 2018 to 2020 were dental fillings and the pulp treatment group for NHI patients. The types of procedures that contribute the largest income to dental clinics from general patients each year are somewhat different, namely heavy scaling in 2018 , very large composite fillings in 2019 and rubber replacement in 2020. In NHI patients, the types of procedures that contribute to dental 
poly income most tend to be the same from 2018-2020, namely multiple root canal preparation + dressing package 3. In 2018-2020 general dentist services accounted for the largest income for dental clinic from general patients, while for NHI patients' general dentists contributed the largest income in 2018-2019 and in 2020 specialist dentists contributed the largest income for dental clinic of Rajawali Citra hospital.

\section{REFERENCES}

[1] Muslimah, Andayani, T. M., Pinzon, R., \& Endarti, D, 2017. Perbandingan Biaya Riil Terhadap Tarif INA CBG's Penyakit Stroke Iskemik di RS Bethesda Yogyakarta, Jurnal Manajemen dan Pelayanan Farmasi, Vol. 7, No. 2, hh. 105-114.

[2] Nurhatasa, A., \& Hamzah, M. I, 2013, Analisis Pengakuan Pendapatan dan Beban Serta Kaitannya Terhadap Insentif Karyawan Pada Rumah Sakit Medika Permata Hijau, JEBI: Jurnal Ekonomi Bisnis Indonesia, Vol. 81, hh. 1-15,

[3] Kasmir, 2017, Analisis Laporan Keuangan, Raja Grafindo Persada, Jakarta.

[4] Freedman, S, 2012, Health Insurance and Hospital Technology Adoption, Health Economics and Health Services Research, Vol. 23, hh. 177-198.

[5] Yadav, K., \& Prakash, S, 2016, Dental Caries: A Review, Asian Journal of Biomedical and Pharmaceutical Sciences, Vol. 653, hh. 01-07.

[6] Badan Penelitian dan Pengembangan Kesehatan, 2018, Riset Kesehatan dasar 2018, Kementrian Keseahtan RI, Jakarta.

\section{AUTHORS}

First Author - Shanti Yuniwardani, Universitas Muhammadiyah Yogyakarta and email: shanti.yuni@gmail.com

Second Author - Iwan Dewanto, Universitas Muhammadiyah Yogyakarta, Indonesia and email iwan.dewanto@umy.ac.id

Correspondence Author - Shanti Yuniwardani, email shanti.yuni@gmail.com, contact number. Mobile No. +62 896-8363-4535 